\title{
The impact of mechanical shear on membrane flux and energy demand
}

\author{
T. Zsirai ${ }^{\mathrm{a}, \mathrm{b}}$, H. Qiblawey ${ }^{\mathrm{b}}$, M. J. A-Marri ${ }^{\mathrm{a}}$, S. Judd ${ }^{\mathrm{a}, \mathrm{c}^{*}}$ \\ ${ }^{a}$ Gas Processing Center, Qatar University, Doha, Qatar \\ ${ }^{\mathrm{b}}$ Department of Chemical Engineering, Qatar University, Doha, Qatar \\ ${ }^{\mathrm{c}}$ Cranfield Water Science Institute, Cranfield University, UK \\ *Corresponding author, simon.judd@qu.edu.qa.
}

\section{Abstract}

The use of forced mechanical shear for both disc membranes (rotating and vibrating disc filtration, RDF and VDF respectively) and hollow fibres (vibrating HF membranes, VHFM) is reviewed. These systems have been extensively studied and, in the case of the disc membranes, have reached commercialisation and proven effective in achieving transmembrane pressure (TMP) control for various challenging feed waters.

The effects of operating conditions, namely shear rate as enhanced by rotation and vibration speed and TMP, and feed water quality on the filtration flux and specific energy consumption are quantified as part of the review. A new relationship is revealed between the two empirical constants governing the classical relationship between membrane flux and shear rate, and a mathematical correlation proposed accordingly. A study of available information on energy reveals that operation and lower shear rates (i.e. rotation or vibration speeds) and more conservative fluxes leads to lower specific energy demands in $\mathrm{kWh} \mathrm{m}^{-3}$ permeate, albeit with a larger required membrane area.

Keywords mechanical shear, rotating membranes, vibrating membranes, hollow fibre, specific energy demand

\section{Introduction}

All membrane processes where there is relative motion between the membrane and the fluid involve shear. In conventional crossflow membrane filtration shear is generated by pumping the liquid through a membrane channel. For a submerged membrane process, and specifically a membrane bioreactor (MBR), it is generated through the action of air bubbles scouring the membrane surface. An alternative to promoting the liquid motion, however, is to apply shear mechanically to move the membrane as opposed to the liquid.

The paper aims to identify possible relationships between flux and membrane motion which determine the nature of the impact of shear on both productivity (i.e. permeate flux) and specific energy demand (energy per unit volume of permeate). These aspects are considered for specifically for both rotating and vibrating membrane technologies of flat disc and hollow fibre membrane configuration.

Published by Elsevier. This is the Author Accepted Manuscript issued with:

Creative Commons Attribution Non-Commercial No Derivatives License (CC:BY:NC:ND 4.0).

The final published version (version of record) is available online at DOI:10.1016/j.memsci.2016.06.010.

Please refer to any applicable publisher terms of use. 


\section{Rotating and vibrating disc filters (RDF and VDF)}

\subsection{Shear impacts on flux}

The use of mechanically-imposed shear to enhance flux by reducing both concentration polarisation (CP) and/or the development of the filter cake is well established [1-3]. Dynamic or shear-enhanced filtration involves creating shear at the membrane by rotating (and thus rotating disc filtration or RDF) or vibrating (hence VDF) the membrane or some component near the membrane surface, with RDFs sometimes using overlapping multiple shaft discs (MSDs). The movement may be either axial or, more usually, torsionally around the axis for disc membranes, or horizontal (lateral) or vertical for rectangular membranes (Fig. 1). Using dynamic filtration has been shown by various investigators [4-11] to greatly suppress CP limitations, reducing the membrane area requirement [12]. The process appears especially effective for high-value, small-scale duties, including various dairy industry applications $[6,13-25]$, the treatment of yeast dispersions and bovine albumin solutions $[4,5,26]$, pulp and paper industry applications [7,27] and specialist beverage process separations, such as the treatment of chicory juice [28,29,30] or sugar beet juice [31,32]. However, it has also found use in landfill leachate treatment [33,34], arsenic removal from drinking water $[11,35]$, treatment of brine and brackish water [36,37,38], removal of natural organic matter $[10,39,40]$, livestock wastewater treatment $[8,41,42]$, dishwasher detergent wastewater and surfactant solution treatment [43-44], separation of microalgae [45, 46] and Anammox sludge consolidation [47].

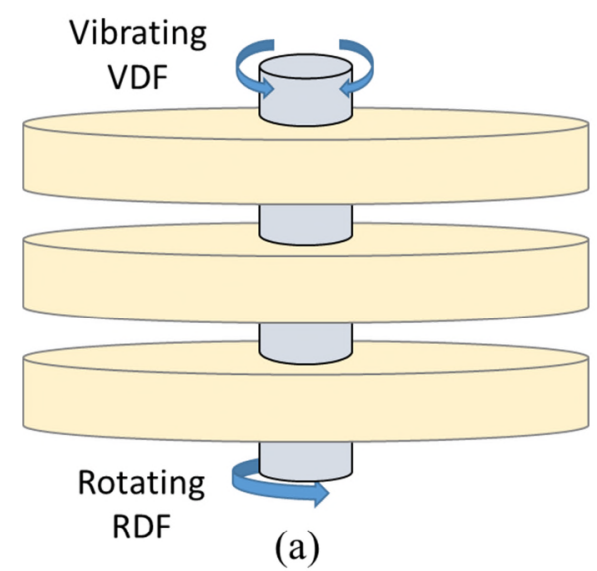

(a)

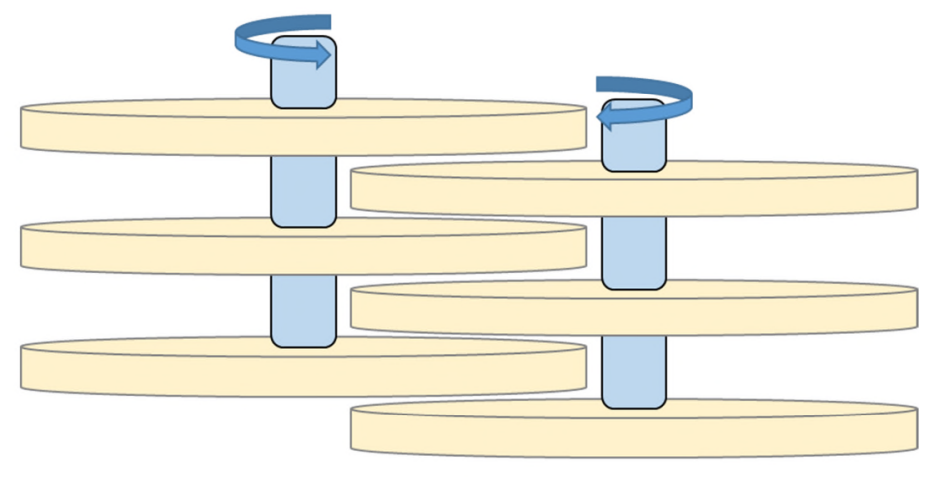

(b)

(c)

Figure 1. Membrane technologies with modes of movement: (a) rotating and vibrating disc filters (RDF and VDF), indicating torsional motion; (b) multiple shaft disc (MSD), overlapping, (c) vibrating membrane (e.g. hollow fibre, VHFM). 
Although most dynamic filtration investigations have shown filtration flux to increase with increasing surface shear, the precise relation evidently depends on feed type and concentration $[4,5,48]$, pore size of the applied membrane $[5,31,35,40]$ and system operating conditions $[48,49]$. However, the flux generally increases with vibration/rotation rate and amplitude, with rejection capability also affected in some instances $[9,36,37,40]$.

The correlation of flux with shear takes the general form [3]:

$$
J=k \gamma^{n}
$$

where $\gamma$ is the shear rate, in units of inverse time, and $k$ and $n$ are empirical constants. In this simple relationship the coefficient $k$ can be viewed as the strength of the correlation and the exponent $n$ the sensitivity, with respect to flux vs. shear.

A summary of available data for $k$ and $n$ values obtained for primarily vibrating and rotating ultra/microfiltration membrane systems (Table 1) indicates a number of interesting trends:

1. Exponent values relate primarily to feedwater characteristics. For example, reported values of $n$ for skimmed milk, from data derived from four independent studies, lie between 0.48 and 0.60 . The value appears independent of either the technology or the membrane characteristics (and specifically the material and pore size),

2. High exponent values are associated with high viscosity, which in turn relates to solid or solute concentration. Examples of such matrices include systems where the feed is being concentrated - sometimes referred to as "volume reduction" [49-51] - or innately highsolids systems such as fermentation broths [51] and soya milk [14-15].

3. There is also some dependence of $n$ on applied pressure [44] across ranges of 0.5-10 bar for RDFs [4,48,49,52], 0.8-15 bar for VDFs [4,48,49,53], up to 3 bar for MSDs [44] and 0.005-0.008 bar for a vibrating hollow fibre membrane (VHFM) [54]. At lower pressures the initial flux has been reported to increase more rapidly with increasing shear than at higher pressures.

4. Exponent values tend to be higher for smaller pore sized (ultrafiltration, UF) membranes, as compared with coarser (microfiltration, MF) ones, under otherwise comparable conditions $[5,55]$.

5. The coefficient value tends to increase with decreasing exponent value, especially at lower shear rate $\left(<2000 \mathrm{~s}^{-1}\right)$. According to Beier et al. [56], this increase relates to the macromolecular content of the feedwater which tends to lower the critical flux. On the other hand, the exponent trend indicates the rate of flux increase, or the efficacy of the applied shear, and tends to increase with increasing macromolecule content. 
Table 1: $\mathbf{n}$ and $\mathbf{k}$ data for membrane filtration systems

\begin{tabular}{|c|c|c|c|c|c|c|c|}
\hline Technol. & Feed & Membrane & Flux (LMH) & Shear rate $\left(\mathrm{s}^{-1}\right)$ & Expont. & Coefficient & Source \\
\hline VDF & UHT skimmed milk & NF - 150-300 Da (Desal) & $20-200$ & $11500-107000$ & 1.560 & 0.00003 & {$[6]$} \\
\hline VDF/RDF & Yeast & MF - $0.2 \mu \mathrm{m}$ (sym. Nylon) & $50-550$ & $45000-300000$ & 1.459 & 0.0000043 & [49] \\
\hline VDF & UHT skim milk & UF - $50 \mathrm{kDa}(\mathrm{PES})$ & $20-80$ & $40000-110000$ & 1.257 & 0.000034 & [49] \\
\hline RDF & Soya milk & UF - $50 \mathrm{kDa}$ (PES) & $10-100$ & $23000-200000$ & 0.778 & 0.0069 & {$[15]$} \\
\hline RDF & Soya milk & $\mathrm{UF}$ - $50 \mathrm{kDa}$ (PES) & $13-100$ & $10000-220000$ & 0.720 & 0.013 & [14] \\
\hline RDF & Ferm. Biomass, $30^{\circ} \mathrm{C}$ & $\mathrm{MF}-0.2 \mu \mathrm{m}$ & $25-400$ & 5-225 $\mathrm{Pa}$ & 0.720 & 4.61 & [51] \\
\hline RDF & Ferm. Biomass, $36^{\circ} \mathrm{C}$ & $\mathrm{MF}-0.2 \mu \mathrm{m}$ & $40-800$ & $6-400 \mathrm{~Pa}$ & 0.680 & 17.54 & [60] \\
\hline RDF & UHT skim milk & $\mathrm{UF}-50 \mathrm{kDa}(\mathrm{PES})$ & $40-300$ & $18000-290000$ & 0.595 & 0.143 & [49] \\
\hline VDF & UHT skim milk & $\mathrm{UF}$ - $50 \mathrm{kDa}$ (PES) & $30-100$ & $12000-120000$ & 0.587 & 0.110 & [49] \\
\hline VDF & UHT skim milk & $\mathrm{UF}-50 \mathrm{kDa}(\mathrm{PES})$ & $20-70$ & $10000-100000$ & 0.576 & 0.09 & [49] \\
\hline RDF & UHT skim milk & UF - $50 \mathrm{kDa}(\mathrm{PES})$ & $40-170$ & $9000-110000$ & 0.572 & 0.199 & [57] \\
\hline RDF & UHT skim milk & UF - $50 \mathrm{kDa}(\mathrm{PES})$ & $40-105$ & $20000-110000$ & 0.572 & 0.134 & [49] \\
\hline VDF & UHT skim milk & UF - 50 kDa (PES) & $10-60$ & $2800-55000$ & 0.567 & 0.121 & {$[4]$} \\
\hline RDF & Yeast & MF - $0.2 \mu \mathrm{m}$ (sym. Nylon) & $40-80$ & $20000-70000$ & 0.567 & 0.1402 & {$[49]$} \\
\hline VDF & UHT skim milk & UF - $50 \mathrm{kDa}(\mathrm{PES})$ & $10-55$ & $2800-70000$ & 0.560 & - & [58] \\
\hline RDF & UHT skim milk & UF - 50 kDa (PES) & $50-300$ & $13000-230000$ & 0.552 & 0.301 & [57] \\
\hline VDF & UHT skim milk & UF - 50 kDa (PES) & $15-80$ & $5000-110000$ & 0.533 & 0.168 & [49] \\
\hline VDF & UHT skim milk & UF - $50 \mathrm{kDa}$ (PES) & $15-80$ & $3000-60000$ & 0.533 & 0.217 & {$[4]$} \\
\hline VDF & Powder milk & UF - $10 \mathrm{kDa}$ (PES) & $26-55$ & $18000-65000$ & 0.520 & 0.2 & [13] \\
\hline VDF & Yeast & MF - $0.2 \mu \mathrm{m}$ (sym. Nylon) & $38-65$ & $33000-90000$ & 0.502 & 0.207 & [49] \\
\hline RDF & UHT skim milk & $\mathrm{UF}-50 \mathrm{kDa}(\mathrm{PES})$ & $60-200$ & $14000-200000$ & 0.500 & 0.36 & [52] \\
\hline VDF & Yeast & MF - $0.2 \mu \mathrm{m}$ (sym. Nylon) & $40-70$ & $12000-35000$ & 0.500 & 0.3489 & [48] \\
\hline RDF & Linseed oil & UF - 50 kDa (PES) & $20-180$ & $4000-350000$ & 0.477 & 0.364 & [55] \\
\hline VDF & UHT skim milk & MF - $0.1 \mu \mathrm{m}$ (PTFE) & $20-35$ & $3000-11000$ & 0.476 & 0.41 & {$[4]$} \\
\hline VDF & Powder milk & $\mathrm{UF}-10 \mathrm{kDa}(\mathrm{PES})$ & $20-90$ & $5000-100000$ & 0.471 & 0.352 & [53] \\
\hline VDF & Bovine albumin & UF - 50 kDa (PES) & $\begin{array}{l}50-120 \text { at } 10^{\circ} \mathrm{C}, \\
90-400 \text { at } 35^{\circ} \mathrm{C}\end{array}$ & $\begin{array}{l}1200-30000 \text { at } 10^{\circ} \mathrm{C}, \\
1700-40000 \text { at } 30^{\circ} \mathrm{C}\end{array}$ & 0.426 & $\begin{array}{l}2.86 \text { at } 10^{\circ} \mathrm{C}, \\
3.95 \text { at } 35^{\circ} \mathrm{C}\end{array}$ & [48] \\
\hline VHFM & Yeast & MF $-0.36-0.5 \mu \mathrm{m}$ & $0-25$ & $0-2000$ & 0.376 & 2.099 & {$[56]$} \\
\hline RDF & Linseed oil & MF - $0.15 \mu \mathrm{m}$ (PVDF) & $30-130$ & $4000-400000$ & 0.364 & 1.82 & {$[55]$} \\
\hline MSD & $\mathrm{CaCO}_{3}$ & $\mathrm{MF}-0.2 \mu \mathrm{m}$ (ceramic) & $300-900$ & $6000-60000$ & 0.351 & 18.861 & [44] \\
\hline VHFM & Yeast & $\mathrm{MF}-0.36-0.5 \mu \mathrm{m}$ & $0-16$ & $0-2000$ & 0.323 & 1.7887 & [56] \\
\hline MSD & $\mathrm{CaCO}_{3}$ & MF - $0.2 \mu \mathrm{m}$ (nylon) & $400-800$ & $5000-20000$ & 0.305 & 38.266 & {$[44]$} \\
\hline VHFM & Yeast & $\mathrm{MF}-0.36-0.5 \mu \mathrm{m}$ & $15-70$ & $0-2000$ & 0.264 & 8.2167 & [59] \\
\hline VSEP & UHT skim milk & MF $-0.1 \mu \mathrm{m}$ (PTFE) & $35-50$ & $11000-70000$ & 0.215 & 4.781 & {$[4]$} \\
\hline VSEP & Yeast & MF - $0.2 \mu \mathrm{m}$ (sym. Nylon) & $30-40$ & $2000-12000$ & 0.190 & 6.619 & [48] \\
\hline VSEP & Yeast & MF - $0.2 \mu \mathrm{m}$ (sym. Nylon) & $28-38$ & $6500-33000$ & 0.189 & 5.44 & [49] \\
\hline RDF & Yeast & MF $-0.2 \mu \mathrm{m}$ (sym. Nylon) & $30-40$ & $5500-20000$ & 0.186 & 6.17 & [49] \\
\hline
\end{tabular}


Whilst it has been suggested that shear impacts pertain to the technology [49], evidence suggests that there is a universal relationship relating $n$ to $k$. A correlation of these two parameters reveals a log:normal relationship (Fig. 2), with an $\mathrm{R}^{2}$ value of 0.98 , based on 34 of the 38 data points in Table 1. Thus, for these data, based on units of $\mathrm{s}^{-1}$ for shear and LMH for flux in Equation 1:

$$
n=(1.98-\log k) / 5.04
$$

Simplifying the two empirical constants in the above equation, Equation 1 becomes:

$$
J \sim 10^{(2-5 n)} \gamma^{n}
$$

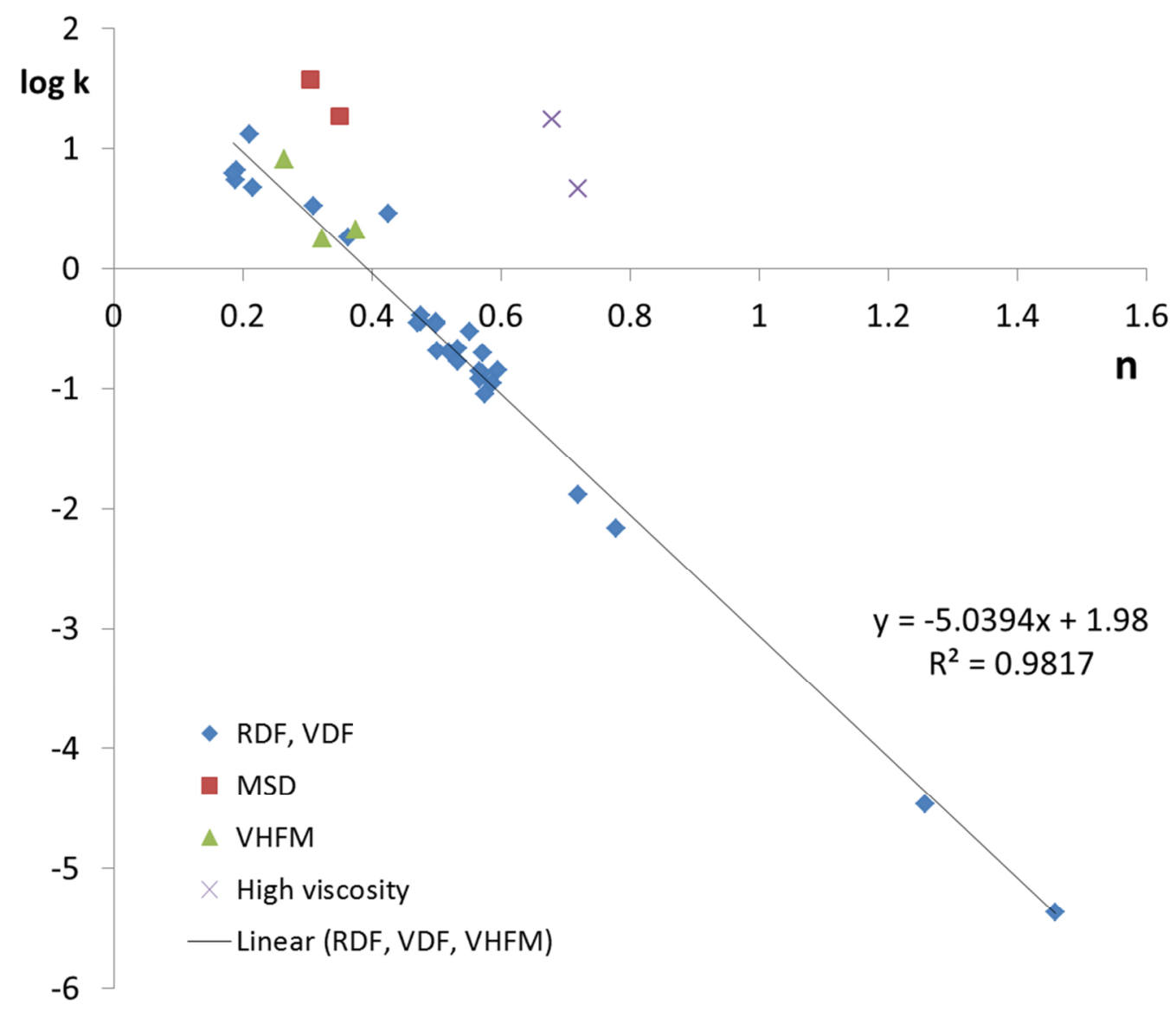

Figure 2. Correlation of $n$ and $k$ parameters in a log:normal relationship

The relationship appears to apply for all data, albeit with a limited data set for the VHFM technology, other than those relating either to the multishaft disk (MSD) technology or to a feedwater matrix comprising extracellular polysaccharides generated by fermentation of biomass at a concentration of $1.4-2.5 \mathrm{~g} / 1$ [51, 60]. For the latter especially, the flux generated is far more sensitive to shear than Equation 3 implies, most likely because of the differing rheological behaviour of this particular fluid [60]. These anomalies aside, for mechanical systems demonstrating classical behaviour the flux sustained by an applied shear can be estimated from Equation 3, provided the exponent value $n$ is known or can be derived. 


\subsection{Shear impacts on energy demand, disc membranes}

Whilst the relationship between the strength $(k)$ and sensitivity $(n)$ parameters shown in Figure 1 is of interest, of greater practical significance is the impact of shear (or rotation speed) on overall energy demand $E$ in $\mathrm{kWh}$ per $\mathrm{m}^{3}$ permeate. Such relationships are specific to the disc membrane technology and size, since the total energy required to rotate shaft is only marginally affected by the number of discs attached to it. The absolute energy demand thus decreases significantly, from several hundred $\mathrm{kWh}$ per $\mathrm{m}^{3}$ permeate for a single disc [61] with the increasing number of discs on the shaft. Trends in energy demand, on the other hand, may not necessarily be dependent on the number of discs.

The energy consumption per $\mathrm{m}^{3}$ permeate (specific energy demand, $E$ ) for a single RDF is represented by

$$
E=W_{d} / Q_{f}
$$

where $W_{d}$ is the sum of power of the rotating disk motor and feed pump (kW) and $Q_{f}$ is the permeate flow rate $\left(\mathrm{m}^{3} \cdot \mathrm{h}^{-1}\right)$ and has been defined as [21]:

$$
W_{d}=0.141 \exp (0.000756 N)
$$

where $N$ is the rotating speed of disk motor (RPM).

However, power has also been defined solely in terms of the friction forces exerted by the fluid [51]. The net power $W_{N}$ is then given by the difference between the power demanded with the fluid in place $\left(W_{d}\right)$ and that without the fluid $\left(W_{o}\right)$ determined at the same speed:

$$
W_{N}=W_{d}-W_{o}
$$

This definition leads to significantly lower values of $E$ with a more pronounced dependency on shear (or rotation speed) due to the rapid decrease in friction forces at low shear.

Notwithstanding the nature of its definition, correlations of the change in $E$ with key system parameters (Table 2) based on data reported by various authors $[21,28,30,51,52,55,60]$ for single-disc studies indicate significant differences in such correlations across the different studies. Thus, an increased membrane pore size has been shown to both increase [28] and decrease [21] the energy demand by factors of between 1.5 and 2.2 depending on the membrane and suspended matter characteristics, feed concentration, and operating pressure. However, there appears to be a threshold value beyond which further shear does not increase the flux [44], such that $E$ always increases beyond this point. The solute or suspended matter concentration, as implied by the volume reduction rate (VRR) has been shown to increase the absolute value of $E$ but not the trend against shear rate [21].

More representative absolute $E$ values are provided by systems based on multiple discs on either single or multiple shafts. Figures reported for demonstration and commercial RDF systems (Table 3 ) indicate $E$ values predominantly in the range of $0.7-11 \mathrm{kWh} \mathrm{m}^{-3}$ $[16,44,45,57]$ based on the definition of $E$ (Equation 6) provided by Brou et al., [51], and 3-6 $\mathrm{kWh} \mathrm{m}^{-3}$ based on the classical definition (Equation 4). In the case of commercial VDF systems, the most prominent being the established $V$-Sep technology, $E$ values within a relatively narrow range have been reported; $1.8 \mathrm{kWh} . \mathrm{m}^{-3}$ for skimmed milk and brackish water [53] cf. to $2.1 \mathrm{kWh} . \mathrm{m}^{-3}$ for brackish water desalination [38]. A recently commercialized RDF system for biological wastewater treatment applications [63] operates at the lowest rotation speeds on 100-140 RPM and provides the lowest $E$ value $\left(0.63 \mathrm{kWh} . \mathrm{m}^{-3}\right)$ of those tabulated. 
Table 2: Published RDF data, bench-scale

\begin{tabular}{|c|c|c|c|c|c|c|c|}
\hline $\begin{array}{l}\text { Membrane, } R D F \\
\text { technology }\end{array}$ & Matrix & Parameter change, $\gamma, N, d_{p}, P, C^{2}$ & $P($ bar $)$ & $\begin{array}{l}\text { Flux range } \\
(L M H)\end{array}$ & $\begin{array}{l}\text { E factorial } \\
\text { change }\end{array}$ & $\begin{array}{c}E \\
\text { Equation }\end{array}$ & Ref \\
\hline $50 \mathrm{kDa}, 6 \mathrm{~mm}$ & Chicory Juice & $\gamma, 8.5$-fold increase from $12,000 \mathrm{~s}^{-1}$ & 2 & $172-426$ & 2.48 & 5 & {$[44]$} \\
\hline $50 \mathrm{kDa}, 6 \mathrm{~mm}$ & Chicory Juice & $\gamma, 8.5$-fold increase from $12,000 \mathrm{~s}^{-1}$ & 4 & $155-431$ & 2.78 & 5 & {$[44]$} \\
\hline $50 \mathrm{kDa}, 6 \mathrm{~mm}$ & Chicory Juice & $\gamma, 8.5$-fold increase from $12,000 \mathrm{~s}^{-1}$ & 4 & $251-716$ & 2.85 & 5 & {$[44]$} \\
\hline $\begin{array}{l}0.15,0.2,0.45 \mu \mathrm{m} \\
100 \mathrm{kDa}, 6 \mathrm{~mm} \\
\text { vanes }\end{array}$ & Chicory Juice & $\begin{array}{l}d_{p}, 0.15-0.45 \mu \mathrm{m}, \mathrm{N}, 1000-2000 \mathrm{RPM} ; \gamma \\
\text { 3.4-fold increase from } 73,000 \mathrm{~s}^{-1}\end{array}$ & 0.75 & $60-320$ & $1.7-2.5$ & 5 & [28] \\
\hline MF, smooth & $\begin{array}{l}\text { Fermentation } \\
\text { biomass }\end{array}$ & $\begin{array}{l}N, 5 \text {-fold increase from } 500 \mathrm{RPM} ; \mathrm{P}, \\
20-25 \text {-fold increase from } 6 \mathrm{~Pa}\end{array}$ & $<0.3$ & $25-200$ & 9.2 & 6 & {$[51]$} \\
\hline MF, $6 \mathrm{~mm}$ vanes & $\begin{array}{l}\text { Fermentation } \\
\text { biomass }\end{array}$ & $\begin{array}{l}N, 5 \text {-fold increase from } 500 \mathrm{RPM} ; \mathrm{P}, \\
20-25 \text {-fold increase from } 6 \mathrm{~Pa}\end{array}$ & $<0.6$ & $40-400$ & 11.3 & 6 & {$[51]$} \\
\hline MF, $2 \mathrm{~mm}$ vanes & $\begin{array}{l}\text { Fermentation } \\
\text { biomass }\end{array}$ & $\begin{array}{l}N, 5 \text {-fold increase from } 500 \mathrm{RPM} ; \mathrm{P}, \\
20-25 \text {-fold increase from } 6 \mathrm{~Pa}\end{array}$ & $<0.6$ & $35-370$ & 10.0 & 6 & {$[51]$} \\
\hline MF, smooth & Baker's yeast & $N, 5$-fold increase from $500 \mathrm{RPM}$ & $<0.9$ & $60-300$ & 8.7 & 6 & {$[60]$} \\
\hline MF, $6 \mathrm{~mm}$ vanes & Baker's yeast & $N, 5$-fold increase from 500 RPM & $<1.2$ & $150-600$ & 11.5 & 6 & {$[60]$} \\
\hline MF, $6 \mathrm{~mm}$ vanes & Baker's yeast & $N, 5$-fold increase from $500 \mathrm{RPM}$ & $<1.2$ & $300-1000$ & 30 & 6 & {$[60]$} \\
\hline $\begin{array}{l}\text { PVDF, } 0.15 \mu \mathrm{m} \text {, } \\
\text { with vanes }\end{array}$ & Linseed oil & $\begin{array}{l}N, 5.5 \text {-fold increase from } 500 \mathrm{RPM} ; \gamma, \\
22-24 \text {-fold increase from } 12,000 \mathrm{~s}^{-1}\end{array}$ & $<0.9$ & $35-130$ & 7.8 & 6 & {$[55]$} \\
\hline $\begin{array}{l}\text { PVDF, } 0.15 \mu \mathrm{m}, \\
\text { smooth disk }\end{array}$ & Linseed oil & $\begin{array}{l}N, 5.5 \text {-fold increase from } 500 \mathrm{RPM} ; \gamma, \\
22-24 \text {-fold increase from } 12,000 \mathrm{~s}^{-1}\end{array}$ & $<0.35$ & $18-95$ & 6 & 6 & {$[55]$} \\
\hline $\begin{array}{l}\text { PES } 50 \mathrm{kDa} \text { disk } \\
\text { with vanes }\end{array}$ & Linseed oil & $\begin{array}{l}N, 5.5 \text {-fold increase from } 500 \mathrm{RPM}, \gamma \\
22-24 \text {-fold increase from } 12,000 \mathrm{~s}^{-1}\end{array}$ & $<0.4$ & $20-170$ & 8.8 & 6 & {$[55]$} \\
\hline $\begin{array}{l}\text { PES } 50 \mathrm{kDa} \text { smooth } \\
\text { disk }\end{array}$ & Linseed oil & $\begin{array}{l}N, 5.5 \text {-fold increase from } 500 \mathrm{RPM} ; \gamma \\
22-24 \text {-fold increase from } 12,000 \mathrm{~s}^{-1}\end{array}$ & $<1$ & $12-95$ & 7 & 6 & {$[55]$} \\
\hline $\begin{array}{l}N F 270^{1}, 6 \mathrm{~mm} \\
\text { vanes }\end{array}$ & Skimmed milk & $\begin{array}{l}C, \sim 4 \text {-fold increase (through volume } \\
\text { reduction rate, VRR) }\end{array}$ & 10 & $\begin{array}{l}100-500 \\
100-210\end{array}$ & 2.08 & 5 & {$[64]$} \\
\hline $\begin{array}{l}N F 270^{1}, 6 \mathrm{~mm} \\
\text { vanes }\end{array}$ & Skimmed milk & $\begin{array}{l}P, 2 \text {-fold increase from } 20 \mathrm{bar}, \mathrm{VRR}, \\
\text { 4-fold increase }\end{array}$ & - & $\begin{array}{l}1000-350 \\
45-100\end{array}$ & $0.3-0.5$ & 5 & {$[64]$} \\
\hline $\begin{array}{l}\text { PES } 50 \mathrm{kDa} \text { smooth } \\
\text { and small disk }\end{array}$ & UHT skim milk & $N$, 5-fold increase from 500 RPM & $\begin{array}{l}2 @ \\
45^{\circ} \mathrm{C}\end{array}$ & $50-130$ & 11.3 & 6 & {$[57]$} \\
\hline $\begin{array}{l}\text { PES } 50 \mathrm{kDa} \text { small } \\
\text { disk with vanes }\end{array}$ & UHT skim milk & $N$, 5-fold increase from $500 \mathrm{RPM}$ & $\begin{array}{l}2 @ \\
45^{\circ} \mathrm{C}\end{array}$ & $40-145$ & 30 & 6 & {$[57]$} \\
\hline
\end{tabular}


Table 3: Published RDF and MSD data, demonstration/commercial scale: response of SED to specific parameters

\begin{tabular}{|c|c|c|c|c|c|}
\hline Commercial technology & Matrix & Parameter change & Conditions & $S E D, \mathrm{kWh}_{\mathrm{m}} \mathrm{m}^{-3}$ & Ref \\
\hline \multicolumn{6}{|l|}{ Rotating } \\
\hline Aaflowsystem, 6 discs/shaft & Mineral suspension, $200 \mathrm{~g} / \mathrm{L}$ & $N=738$ to 1930 RPM & SS., $\mathrm{P}=2.3$ bar, $\mathrm{J}=500-1421 \mathrm{LMH}$ & 8.04 to 4.18 & {$[61]$} \\
\hline Aaflowsystem, 6 discs/shaft & Mineral suspension, $>200 \mathrm{~g} / \mathrm{L}$ & $N=738$ to 1930 RPM & DS., $\mathrm{P}=2.3$ bar, $\mathrm{J}=525-1207 \mathrm{LMH}$ & 8.67 to 6.9 & {$[61]$} \\
\hline Aaflowsystem, 6 discs $/$ shaft $^{1}$ & Mineral suspension, $>200 \mathrm{~g} / \mathrm{L}$ & $N=738$ to 1037 RPM & DS., $\mathrm{P}=3.5$ bar, $\mathrm{J}=1000-1200 \mathrm{LMH}$, vanes & 7 to 5.6 & {$[62]$} \\
\hline Westfalia, 6 discs $/$ shaft $^{2}$, DS. & Mineral suspension, $200 \mathrm{~g} / \mathrm{L}$ & $\begin{array}{l}N=400 \text { to } 1900 \text { RPM } \\
N=400 \text { to } 1900 \text { RPM }\end{array}$ & $\begin{array}{l}\text { Cer. memb., } \mathrm{P}=3 \text { bar, } \mathrm{J}=600-1300 \text { LMH } \\
\text { Polym memb., } \mathrm{P}=3 \text { bar, } \mathrm{J}=600-1700 \mathrm{LMH}\end{array}$ & $\begin{array}{l}0.75 \text { to } 6.5 \\
1.75 \text { to } 11\end{array}$ & $\begin{array}{l}{[44]} \\
{[44]}\end{array}$ \\
\hline Westfalia, 6 discs $/$ shaft $^{2}$, DS. & Skimmed milk & $N=1500 \mathrm{RPM}$ & Cer. memb., $\mathrm{P}=6$ bar, $\mathrm{J}=86.7$ & 10.8 & {$[16]$} \\
\hline Spintek, 25-disc unit $\left(2.25 \mathrm{~m}^{2}\right)$ & River water screen solids & $\begin{array}{l}C=0.6-5 w t \% \\
C=0.06-1.29 w t \%\end{array}$ & $\begin{array}{l}\text { Cer. memb., } P=2.7-4 \text { bar } \\
\text { Cer. memb., } P=2.7-4 \text { bar, } J=10.6-4.1 \mathrm{LMH}\end{array}$ & $\begin{array}{l}22 \text { to } 33 \\
9.12 \text { to } 23.63\end{array}$ & $\begin{array}{l}{[65]} \\
{[65]}\end{array}$ \\
\hline $\begin{array}{l}\text { Novoflow, } 75 \text {-disk unit }\left(15 \mathrm{~m}^{2}\right) \\
\text { Biobooster, } 36 \text { disc unit } \\
\text { Vibrating }\end{array}$ & $\begin{array}{l}\text { Multiple purpose } \\
\text { MBR sludge }\end{array}$ & $N=100-140 \mathrm{RPM}$ & $\begin{array}{l}\text { SS, 0-6 bar, J = 33-67 LMH } \\
\text { Cer. memb., } 35 \text { LMH, } 0.44 \text { bar }\end{array}$ & $\begin{array}{l}6 \text { to } 3 \\
0.63\end{array}$ & $\begin{array}{l}{[39,67,68]} \\
{[63]}\end{array}$ \\
\hline $\begin{array}{l}\overline{V-S e p, 0.5} \mathrm{~m}^{2} \text { unit } \\
V \text {-Sep, }\end{array}$ & $\begin{array}{l}\text { Skimmed mik } \\
\text { Brackish water }\end{array}$ & $\begin{array}{l}N=60.75 \mathrm{~Hz} \\
N=60.75 \mathrm{~Hz}\end{array}$ & $\begin{array}{l}\text { Polym. memb., } \mathrm{P}=8 \text { bar, } \mathrm{J}=75 \mathrm{LMH} \text {, } \\
\text { Recovery }=75 \%, \mathrm{~J}=20.4 \mathrm{LMH}\end{array}$ & $\begin{array}{l}1.83 \\
2.1\end{array}$ & $\begin{array}{l}{[53]} \\
{[38]}\end{array}$ \\
\hline
\end{tabular}

SS Single shaft; DS dual shaft (overlapping); Cer. ceramic; Polym. polymeric

${ }^{1} 6$ ceramic membranes on one shaft with 6 non-permeating metallic membranes on the other. 750 rpm metallic disc

${ }^{2} 6$ ceramic or 6 polymeric disks on one shaft and 3 metal disks on the other 
It can be generally surmised from the data in Tables 2 and 3 that an increase in shear generally provides higher fluxes and thus reduces the membrane area requirement, with an expected commensurate decrease in capital cost. However, it does not necessarily follow that there is an accompanying decrease in $E$ - even for full-scale commercial systems. The data in Table 3 suggest that the optimum rotation/vibration rate is likely to be at lower speeds.

\section{Vibrating hollow fibre membranes (VHFMs) and rotating flat sheet membranes (RFSMs)}

The application of mechanical shear to a conventional hollow fibre (HF) and flat sheet (FS) membrane module is a relatively recent area of research, normally relating to immersed membrane bioreactors (iMBRs) but with experimental studies predominantly based on analogues (Table 4). The latter have included macromolecules such as baker's yeast solution $[26,54,56,59,69]$ and bentonite $[70,71]$ or particulate such as alginate [70] to mimic foulants or kaolin suspensions [64], with three reported studies of MBR sludge [72-75]. Data from the single VHFM study in which shear rates are reported $[56,59]$ are included in Table 1 and Figure 1. Shears attainable for such systems, which have employed a wide variety of motion types, are at the low end (20-2000 s $\left.\mathrm{s}^{-1}\right)$ of those attainable for disc membrane technologies where the maximum shear is only limited by the rotation speed. However, as is evident from Fig. 1, the quantitative impact of shear on flux for HF and FS membranes does not differ from that recorded for disc membranes; Equation 3 appears to be applicable for enforcedshear systems generally.

Quantitative improvements in flux values, reaching values as high as $70 \mathrm{LMH}$, have been recorded from the application of shears of up to $2000 \mathrm{~s}^{-1}$ to VHFM systems [59] for vertical vibration. Even higher fluxes of $130 \mathrm{LMH}$ were reached on applying both transverse and vertical movement [59]. For other studies at lower applied shears (1200-1400 s $\mathrm{s}^{-1}$ ), fluxes achieved were commensurately lower (30-60 LMH). Frequencies and amplitudes applied have varied from 6 to $30 \mathrm{~Hz}$ and 2 to $40 \mathrm{~mm}$ respectively, with some equivocation as to which of these parameters is of greatest importance in promoting flux $[59,64]$.

As with RDS and VDS technologies, $E$ values for VHFM studies are not often reported and are most valid for larger systems. However, the general trend is for comparatively low vibration rates, with values as low as $1.7 \mathrm{~Hz}$ [69] and $0.38 \mathrm{~Hz}[72,73,76]$ being reported. This leads to commensurately low shear rates, but also low power consumption. Consequently, relatively modest fluxes (in the region of 30-40 LMH) can yield average $E$ values of around $0.91 \mathrm{kWh} . \mathrm{m}^{-3}$, as demonstrated for a vertical VHFM MBR system [72,73,76]. Specific energy demand was lowered from 0.29 to $0.15 \mathrm{kWh} \mathrm{m}^{-3}$ and fluxes increased from 46 to 86 $\mathrm{LMH}$ when combined vertical and horizontal displacement was applied using turbulence promoting attachments (vanes) along with aluminum chlorohydrate $(\mathrm{ACH})$ coagulant for a VHFM MBR system [69]. An RFSM system operating at low rotation speeds (5 RPM), with a commensurately low power, has been reported as attaining a flux of $105 \mathrm{LMH}$ when challenged with a skimmed milk feed, yielding an $E$ of $0.53 \mathrm{kWh} \cdot \mathrm{m}^{-3}$ [26].

The VHFM studies appear to be similar in principle to the RDS Grundfos Biobooster technology (Table 2, [63]), which operates at a frequency of 1.6 to $2.3 \mathrm{~Hz}$ with a correspondingly conservative flux (35 LMH). However, the reported $E$ of $0.63 \mathrm{kWh} / \mathrm{m}^{-3}$ for membrane permeation is significantly higher than the corresponding value for the VHFM challenged with a similar matrix of $8-14 \mathrm{~g} / \mathrm{L}$ activated sludge $[72,73,76]$. 
Table 4: Reported data, VHFM and RFSM technologies

\begin{tabular}{|c|c|c|c|c|c|c|c|}
\hline Displacement & $\begin{array}{c}\text { Feed } \\
\text { solution/application }\end{array}$ & $\begin{array}{l}\text { Membrane material, } \\
\text { pore size, area }\end{array}$ & $\begin{array}{l}\text { Maximum flux } \\
(\mathrm{LMH})\end{array}$ & $\begin{array}{c}\text { Vibrating/rotating } \\
\text { frequencies }(\mathrm{Hz}, \\
\text { r/min) amplitude (A) }\end{array}$ & $\begin{array}{l}\text { Shear } \\
\text { rate } \\
(1 / \mathrm{s}) \\
\end{array}$ & $\begin{array}{c}\text { SED } \\
\left(\mathrm{kWh} / \mathrm{m}^{3}\right)\end{array}$ & Source \\
\hline Horizontal (FS) & Aerobic sludge, $10-12 \mathrm{~g} / 1$ & PE, $0.22 \mu \mathrm{m}, 0.096 \mathrm{~m}^{2}$ & 16 & $0-60 \mathrm{~Hz}, 0-2 \mathrm{~mm}$ & - & 2.03 & {$[78]$} \\
\hline Horizontal (FS) & Microalgal broths, - & $\begin{array}{c}\text { PVDF, } 0.036 \text { and } 0.013 \\
\mu \mathrm{m}, 4 \mathrm{~m}^{2}\end{array}$ & $>50$ & $45 \mathrm{~Hz}$ & - & $0.77-0.84$ & [79] \\
\hline Rotational & $\begin{array}{l}\text { Anaerobic sludge, } 8-10 \\
\mathrm{~g} / \mathrm{L}\end{array}$ & $\begin{array}{c}\text { PVDF, } 0.04 \mu \mathrm{m},- \\
0.047 \mathrm{~m}^{2}\end{array}$ & 10 & $4.3 \mathrm{~Hz}$ & - & - & {$[75]$} \\
\hline Horizontal & Aerobic sludge, $8-10 \mathrm{~g} / \mathrm{L}$ & PVDF, $0.04 \mu \mathrm{m},-$ & 40 & $0.38-0.48 \mathrm{~Hz}$ & - & $0.072(40 \mathrm{LMH}, 18 \mathrm{kPa})$ & {$[72,73,76]$} \\
\hline $\begin{array}{l}\text { Axial (vertical) and } \\
\text { lateral movement }\end{array}$ & Bentonite clay & PAN, $0.1 \mu \mathrm{m},-$ & 30 & $10 \mathrm{~Hz}, 5 \mathrm{~mm}$ & - & $16.6 \mathrm{~W}(10 \mathrm{~Hz}, 5 \mathrm{~mm})$ & {$[71]$} \\
\hline $\begin{array}{l}\text { Transverse }^{1} \text { membrane } \\
\text { movement (A); liquid } \\
\text { oscillation (B) }\end{array}$ & Baker's yeast (4 g/l) & PVDF, $0.04 \mu \mathrm{m},-$ & $\begin{array}{c}\text { A:40, B:35 (250\% } \\
\text { enhancement) }\end{array}$ & $\begin{array}{c}\mathrm{A} \text { and B: } 21.8 \mathrm{~Hz}, 2.5 \\
\mathrm{~mm}\end{array}$ & - & $\begin{array}{c}0.20 \text { (30 LMH, } 21.8 \mathrm{~Hz} \\
2.5 \mathrm{~mm} \text { displacement })\end{array}$ & {$[72]$} \\
\hline Vertical vibration & Baker's yeast & $\mathrm{PP}, 0.2 \mu \mathrm{m},-$ & 60 & $1.67-8.35 \mathrm{~Hz}, 40 \mathrm{~mm}$ & $0-1402$ & - & {$[56]$} \\
\hline Vertical vibration & $\begin{array}{l}\text { Pottery clay with high } \\
\text { kaolin content }\end{array}$ & PAN, $\underset{\mathrm{m}^{2}}{0.1-0.2} \mu \mathrm{m}, 3.15$ & 34 & $6-8 \mathrm{~Hz}, 8 \mathrm{~mm}$ & - & - & [64] \\
\hline Vertical vibration & $\begin{array}{l}\text { Separation of protein } \\
\text { (BSA) from baker`s } \\
\text { yeast suspension }\end{array}$ & $\begin{array}{c}\mathrm{PES} / \mathrm{PVP}(98 / 2 \%), 0.3- \\
0.5 \mu \mathrm{m}, 0.0084 \text { and } \\
0.0488 \mathrm{~m}^{2}\end{array}$ & 30 & $20 \mathrm{~Hz}, 1.375 \mathrm{~mm}$ & $0-1230$ & - & {$[80]$} \\
\hline Vertical vibration & $\begin{array}{l}\text { Separation of enzyme } \\
\text { from baker`s yeast } \\
\text { suspension }\end{array}$ & $\begin{array}{l}\text { PES, } 0.36-0.5 \mu \mathrm{m}, \\
\quad 0.0488 \mathrm{~m}^{2}\end{array}$ & 16,25 & $5-25 \mathrm{~Hz}, 0-0.7 \mathrm{~mm}$ & $0-1200$ & - & {$[56]$} \\
\hline Vertical vibration & $\begin{array}{l}\text { Baker`s yeast suspension } \\
\qquad(5 \mathrm{~g} / \mathrm{l})\end{array}$ & PES, 0.36-0.5 $\mu \mathrm{m}$ & $\begin{array}{l}\text { A: } 70(325 \% \\
\text { enhancement) }\end{array}$ & $5-30 \mathrm{~Hz}, 0-1.175 \mathrm{~mm}$ & $\begin{array}{c}22- \\
1936\end{array}$ & - & {$[59]$} \\
\hline $\begin{array}{l}\text { Vertical }(\mathrm{A}), \text { and both } \\
\text { vertical and transverse } \\
\text { movement }(\mathrm{B})\end{array}$ & $\begin{array}{l}\text { Poly-dispersed yeast } \\
\text { cells }\end{array}$ & $0.2 \mu \mathrm{m}, 0.0057 \mathrm{~m}^{2}$ & A: $46, \mathrm{~B}: 86$ & $0-10,2 \mathrm{~mm}$ & $0-2000$ & $\begin{array}{l}0.29(\mathrm{~A}: 1.7 \mathrm{~Hz}, 34 \mathrm{ppm} \\
\mathrm{ACH}) ; 0.15(\mathrm{~B}: 1.7 \mathrm{~Hz} \\
\left.\text { vanes }^{2}, 34 \mathrm{mg} / \mathrm{L} \mathrm{ACH}\right)\end{array}$ & [69] \\
\hline $\begin{array}{l}\text { Rotational (Rotating } \\
\text { FS) }\end{array}$ & $\begin{array}{c}\text { Baker`s yeast suspension } \\
(4.9 \mathrm{~g} / \mathrm{l})\end{array}$ & $\begin{array}{c}\text { PP-NWF, } 3 \mu \mathrm{m}, 0.09 \\
\mathrm{~m}^{2}\end{array}$ & 105 & 5 rotations $/ \mathrm{min}$ & & 0.53 & {$[26]$} \\
\hline Rotational (Round FS) & $\begin{array}{l}\text { Synthetic sewage, MLSS } \\
7-10 \mathrm{~g} / 1\end{array}$ & PVDF, $0.2 \mu \mathrm{m}, 0.12 \mathrm{~m}^{2}$ & $42.5-47.5$ & $15-25$ rotations $/ \mathrm{min}$ & - & - & [81] \\
\hline
\end{tabular}


The only comparable commercial process in terms of energy demand is the established Huber Vacuum Rotating Membrane (VRM) technology. This process employs a membrane which rotates at a speed of only $\sim 2 \mathrm{rpm}$. For this very low rotation speed, the specific energy demanded for the mechanical component of the operation is in the region of $0.015 \mathrm{kWh} / \mathrm{m}^{3}$ permeate [77] - around 40 times less than that for an RDF technology such as the Biobooster. However, the Huber system demands supplementary air scour, adding significantly to the total energy demand. For systems such as the Biobooster and the VRM, intended for bulk wastewater treatment at flows of $500-5000 \mathrm{~m}^{3} / \mathrm{d}$, the total specific energy demand is of pivotal importance. Against, for "high-end" separations where volumes treated are much smaller, there is less onus on reducing energy and more on control of the process mass transfer that the applied shear permits.

\section{Conclusions}

Outputs from a review of available data from studies of rotating and vibrating membrane filters (RMF and VMF), as well as those for a vibrating hollow fibre membrane (VHFM), suggest that there is an overall unifying relationship between flux and shear. With the exception of a few anomalous data relating to either multi-shaft systems or unusually highviscosity (or possibly more generally rheologically distinguished) liquid matrices, most available data suggest that the flux, in LMH, is given approximately by $10^{(2-5 n)} \gamma^{n}$ for shear $\gamma$ expressed in units of $\mathrm{s}^{-1}$. The strength and sensitivity parameters (the coefficient and exponent respectively) thus appear to be related.

Evidence provided by available information on energy demand for commercial-scale equipment suggests that mechanically-imposed shear in membrane processes becomes more energy efficient in terms of $\mathrm{kWh} . \mathrm{m}^{-3}$ permeate at lower shear rates (i.e. rotation or vibration speeds) and commensurately more conservative fluxes. Specific energy demands as low as $0.1 \mathrm{kWh} \mathrm{m}^{-3}$ have been demonstrated for VHFMs operating at vibration rates below $0.5 \mathrm{~Hz}$ (or 30 RPM equivalent) for biological municipal wastewater treatment. This compares with the values of 100-400 RPM or $60.75 \mathrm{~Hz}$ typically respectively employed for RDF and VDF commercial systems dedicated to high-end, low-volume applications. These appear to operate in the range of $0.6-2 \mathrm{kWh} . \mathrm{m}^{-3}$, somewhat higher than the VHFM systems but also offer higher fluxes and thus a reduced membrane area requirement. There is thus the classic tradeoff between CAPEX and OPEX based on both the technology and the application for these technologies.

\section{Acknowledgment}

This work was made possible by the support of a National Priorities Research Programme (NPRP) grant from the Qatar National Research Fund (QNRF), grant reference number NPRP8-1115-2-473.

\section{References}

[1] L.H. Ding, M.Y. Jaffrin, Benefits of high shear rate of dynamic nanofiltration and reverse osmosis: a review, Sep. Sci. and Technol. 49 (2014) 1953-1967. 
[2] M.Y. Jaffrin, Dynamic filtration with rotating disks, and rotating and vibrating membranes: an update, Current Opinion in Chemical Engineering 1 (2012) 171-177.

[3] M.Y. Jaffrin, Dynamic shear-enhanced membrane filtration: A review of rotating disks, rotating membranes and vibrating systems, J. Membr. Sci. 324 (2008) 7-25.

[4] O. Al-Akoum, L.H. Ding, M.Y. Jaffrin, Microfiltration and ultrafication of UHT skim milk with a vibrating membrane module, Sep. Purif. Technol. 28 (2002) 219-234.

[5] O. Al-Akoum, L. Ding, R. Chotard-Ghodsnia, M.Y. Jaffrin, G. Gésan-Guiziou, Casein micelles separation from skimmed milk using a VSEP dynamic filtration module, Desal. 144 (2002) 325-330.

[6] M. Frappart, M.Y. Jaffrin, L.H. Ding, V. Espina, Effect of vibration frequency and membrane shear rate on nanofiltration of diluted milk, using a vibratory dynamic filtration system, Sep. Purif. Technol. 62 (2008) 212-221.

[7] T. Huuhilo, P. Väisänen, J. Nuortila-Jokinen, M. Nyström, Influence of shear on flux in membrane filtration of integrated pulp and paper mill circulation water, Desal. 141 (2001) 245-258.

[8] Sz. Kertész, S. Beszédes, Zs. László, G. Szabó, C. Hodúr, Nanofiltration and reverse osmosis of pig manure: Comparison of results from vibratory and classical modules, Desalin. Water Treat., 14 (2010) 233-238.

[9] W. Shi, M.M. Benjamin, Membrane interactions with NOM and an adsorbent in a vibratory shear enhanced filtration process (VSEP) system, J. Membr. Sci. vol. 312 (2008) 23-33.

[10] K. Takata, K., Yamamoto, R. Bian, Y. Watanabe, Removal of humic substances with vibratory shear enhanced processing membrane filtration, Desal. 117 (1998) 273-282.

[11] S.-H. Yi, S. Ahmed, Y. Watanabe, K. Watari, Arsenic removal by MF membrane with chemical sludge adsorption and NF membrane equipped with vibratory shear enhanced process, Water Sci. and Technol.: Water Supply, 3 (2003) 303-310.

[12] M. Mellal, L.H. Ding, M.Y. Jaffrin, C. Delattre, P. Michaud, J. Courtois, Separation and fractionation of oligouronides by shear-enhanced filtration, Sep. Sci. and Technol. 42 (2007) 349-361.

[13] O. Akoum, R. Chotard-Ghodsnia, L.H. Ding, M.Y. Jaffrin, Ultrafiltration of low-heat and UHT skim milks with a shear-enhanced vibrating filtration system, Separ. Sci. and Technol., 38 (2003) 571-589.

[14] O. Akoum, D. Richfield, M.Y. Jaffrin, L.H. Ding, P. Swart, Recovery of trypsin inhibitor by soy milk ultrafiltration using a rotating disk filtration, Desal. 191 (2006) 438-445.

[15] O. Akoum, D. Richfield, M.Y. Jaffrin, L.H. Ding, P. Swart, Recovery of trypsin inhibitor and soy milk protein concentration by dynamic filtration, J. Membr Sci. 279 (2006) 291-300.

[16] V. Espina, M.F. Jaffrin, M. Frappart, L. Ding, Separation of casein from whey proteins by high shear microfiltration of skim milk using rotating ceramic membranes and organic membranes in rotating disk module, J. Membr. Sci. 325 (2008) 872-879.

[17] V. Espina, M.F. Jaffrin, M. Frappart, L. Ding, Extraction and separation of $\alpha-$ lactoalbumin and $\beta$-lactoglobulin skim milk by microfiltration and ultrafiltration at high shear rates: a feasibility study, Sep. Sci Technol. 44 (2009) 3832-3853.

[18] V. Espina, M.F. Jaffrin, L. Ding, Comparison of rotating ceramic membranes and polymeric membranes in fractionation of milk proteins by microfiltration, Desal. 245 (2009) 714-722.

[19] V. Espina, M.F. Jaffrin, M. Frappart, L. Ding, Separation of casein from whey proteins by dynamic filtration, Desal., 250 (2010) 1109-1112. 
[20] C. Hodúr, S. Kertèsz, J. Csanádi, G. Szabó, Comparison of 3DTA and VSEP systems during the ultrafiltration of sweet whey, Desalin. Water Treat., 10 (2009) 265-271.

[21] J. Luo, L. Ding, Y. Wan, P. Paullier, M.Y. Jaffrin, Application of NF-RDM (nanofiltration rotating disk membrane) module under extreme hydraulic conditions for the treatment of dairy wastewater, Chem. Eng. J. 163 (2010) 307-316.

[22] J. Luo, L. Ding, Influence of $\mathrm{pH}$ on treatment of dairy wastewater by nanofiltration using shear-enhanced filtration system, Desal., 278 (2011) 150-156.

[23] J. Luo, W. Cao, L. Ding, Z Zhu, Y. Wan, M.Y. Jaffrin, Treatment of dairy effluent by shear-enhanced membrane filtration: The role of foulants, Sep. Purif. Technol., 96 (2012) 194-203.

[24] J. Luo, L. Ding, Y. Wan, P. Paullier, M.Y. Jaffrin, Fouling behavior of dairy wastewater treatment by nanofiltration under shear-enhanced extreme hydraulic conditions, Sep. Purif. Technol., 88 (2012) 79-86.

[25] P. Meyer, U. Kulozik, High concentration of skim milk proteins by ultrafiltration: Characterisation of dynamic membrane system with a rotating membrane in comparison with a spiral wound membrane, International Dairy Journal, 51 (2015) 7583.

[26] T. Jiang, H. Zang, F. Yang, D. Gao, H. Du, Relationships between mechanically induced hydrodynamics and membrane fouling in novel rotating membrane bioreactor, Desal. and Wat. Treat., 51 (2013), 2850-2861.

[27] C. Bhattacharjee, P.K. Bhattacharya, Ultrafiltration of black liquor using rotating disk membrane module, Sep. Purif. Techn. 49 (2006) 281-290.

[28] J. Luo, Z. Zhu, L. Ding, O. Bals, Y. Wan, M.Y. Jaffrin, E. Vorobiev, Flux behavior in clarification of chicory juice by high-shear membrane filtration: Evidence for threshold flux, J. Membr. Sci. 435 (2013) 120-129.

[29] Z. Zhu, J, Luo, L. Ding, O. Bals, M.Y. Jaffrin, E. Vorobiev, Chicory juice clarification by membrane filtration using rotating disk module, J. Food Eng., 115 (2013) 264-271.

[30] Z. Zhu, S. Ladeg, L. Ding, O. Bals, N. Moulai-Mostefa, M.Y. Jaffrin, E. Vorobiev, Study of rotating disk assisted dead-end filtration chicory juice and its performance optimization, Ind. Corp. Food. 53 (2014) 154-162.

[31] Z. Zhu, H. Mhemdi, L. Ding, O. Bals, M.Y. Jaffrin, N. Grimi, E. Vorobiev, Dead-end dynamic ultrafiltration of juice expressed from electroporated sugar beets, Food Bioprocess Technol. 8 (2015) 615-622.

[32] Z. Zhu, H. Mhemdi, W. Zhang, L. Ding, O. Bals., M.Y. Jaffrin, N. Grimi, E. Vorobiev, Rotating disk-assisted cross-flow ultrafiltration of sugar beet juice, Food Bioprocess Technol. 9 (2016) 493-500.

[33] G.Y.S. Chan, J. Chang, T.A. Kurniawan, C.-X. Fu, H. Jiang, Y. Je, Removal of nonbiodegradable compounds from stabilized leachate using VSEPRO membrane filtration, Desal. 202 (2007) 310-317.

[34] A.I. Zouboulis, M.D. Petala, Performance of VSEP vibratory membrane filtration system during the treatment of landfill leachates, Desal. 222 (2008) 165-175.

[35] S. Ahmed, M.G., Rasul, M.A. Hasib, Y. Watanabe, Performance of nanofiltration membrane in a vibrating module (VSEP-NF) for arsenic removal, J. Hazard. Mater. 177 (2010) 978-982.

[36] W. Shi, M. Benjamin, Fouling of RO membranes in a vibratory shear enhanced filtration process (VSEP) system, J. Membr. Sci. 331 (2009) 11-20.

[37] W. Shi, M. Benjamin, Effect of shear rate on fouling in a Vibratory Shear Enhanced Processing (VSEP) RO system, J. Membr. Sci. 366 (2011) 148-157. 
[38] A. Subramani, J. DeCarolis, W. Pearce, J.G. Jacangelo, Vibratory shear enhanced process (VSEP) for treating brackish water reverse osmosis concentrate with high silica content, Desal. 291 (2012) 15-22

[39] F. Liebermann, Dynamic cross flow filtration with Novoflow`s single shaft disk filters, Desal. 250 (2010) 1087-1090.

[40] M.D. Petala, A.I. Zouboulis, Vibratory shear enhanced processing membrane filtration applied for the removal of natural organic matter from surface waters, J. Membr. Sci. 269 (2006) 1-14.

[41] S. Atkinson, VSEP vibratory membrane filtration system treats hog manure, Membr. Technol., 1 (2005) 10-16.

[42] J. Lee, S. Kim, J. Choi, H. Hwang, M. Cha, J. Kim, Tertiary treatment of biologically treated piggery wastewater using vibratory shear-enhanced RO membrane, Water Sci. Technol., 49 (2004) 435-442.

[43] J. Luo, L. Ding, Y. Wan, M.Y. Jaffrin, Flux decline control in nanofiltration of detergent wastewater by a shear-enhanced filtration system, Chem. Eng. J., 181-182 (2012c) 397-406

[44] Z. Tu, L. Ding, Microfiltration of mineral suspension using a MSD module with rotating ceramic and polymeric membranes, Sep. Purif. Technol., 73 (2010) 363-370.

[45] M. Frappart, A. Massé, M.Y. Jaffrin, J. Pruvost, P. Jaouen, Influence of hydrodynamics in tangential and dynamic ultrafiltration systems for microalgae separation, Desal. 265 (2011) 279-283.

[46] K.-J. Hwang, S.J. Lin, Filtration flux-shear stress-cake mass relationships in microalgae rotating-disk dynamic microfiltration, Chem. Eng. J. 244 (2014) 429-437.

[47] T. Jiang, H. Zhang, H. Qiang, F. Yang, X. Xu, H. Du., Start-up of the anammox process and membrane fouling analysis in anovel rotating membrane bioreactor, Desal. 311 (2013) 46-53

[48] O. A. Akoum, M.Y. Jaffrin, L. Ding, P. Paullier, C. Vanhoutte, A hydrodynamic investigation of microfiltration and ultrafiltration in a vibrating membrane module, $\mathrm{J}$. Membr. Sci. 197 (2002) 37-52.

[49] M.Y. Jaffrin, L.-H. Ding, O. Akoum, A. Brou, A hydrodynamic comparison between rotating disk and vibratory dynamic filtration systems, J. Membr. Sci., 242, (2004) 155167.

[50] W.F. Blatt, A. Dravid, A.S. Michaels, L. Nelson, Solute polarization and cake formation in membrane ultrafiltration: causes, consequences and control techniques, J.E. Flinn (Ed.), Membr. Sci. Technol., Plenum Press, New York, 1970.

[51] A. Brou, L.H. Ding, P. Boulnois, M.Y. Jaffrin, Dynamic microfiltration of yeast suspensions using rotating disks equipped with vanes, J. Membr. Sci., 197 (2002) 269282.

[52] L.H. Ding, O. Akoum, A. Abraham, M.Y. Jaffrin, Milk protein concentration by ultrafiltration with rotating disk modules, Desal. 114 (2002) 307-311.

[53] O. Akoum, M.Y. Jaffrin, L.-H. Ding, Concentration of total milk proteins by high shear ultrafiltration in a vibrating membrane module, J. Membr. Sci., 247 (2005) 211-220.

[54] A. Altaee, A.E. Al-Rawajfeh, Y.J. Baek, Application of vibratory system to improve the critical flux in submerged hollow fiber MF process, Separ. Sci. and Technol. 45 (2010) 28-34.

[55] L. Li, L. Ding, Z. Tu, Y. Wan, D. Clausse, J.-L., Lanoisellé, Recovery of linseed oil dispersed within an oil-in-water emulsion using hydrophilic membrane by rotating disk filtration system, J. Membr. Sci. 342 (2009) 70-79.

[56] S.P. Beier, G. Jonsson, Separation of enzymes and yeast cells with a vibrating hollow fiber membrane module, Sep. Purif. Technol. 53 (2007) 111-118. 
[57] L.H. Ding, O. Akoum, A. Abraham, M.Y. Jaffrin, High shear skim milk ultrafiltration using rotating disk filtration systems, AIChE Journal 49 (2003) 2433-2441.

[58] O. Akoum, M.Y. Jaffrin, L.H. Ding, M. Frappart, Treatment of dairy process waters using a vibrating filtration system and NF and RO membranes, J. Membr. Sci. 235 (2004) 111-122.

[59] S.P. Beier, M. Guerra, A. Garde, G. Jonsson, Dynamic microfiltration with a vibrating hollow fiber membrane module: Filtration of yeast suspensions, J. Membr. Sci. 281 (2006) 281-287.

[60] A. Brou, M.Y. Jaffrin, L.H. Ding, J. Courtois, Microfiltration and Ultrafiltration of Polysaccharides Produced by Fermentation Using a Rotating Disk Dynamic Filtration System, Biotechnol. Bioeng. 82 (2003) 429-437.

[61] L.H. Ding, M.Y. Jaffrin, M. Mellal, G. He, Investigation of performance of multishaft disk (MSD) system with overlapping ceramic membranes in microfiltration of mineral suspension, J. Membr. Sci., 276 (2006) 232-240.

[62] G. He, L.H. Ding, P. Paullier, M. Y. Jaffrin, Experimental study of a dynamic filtration system with overlapping ceramic membranes and non-permeating disks rotating at independent speeds, J. Membr. Sci., 300 (2007) 63-70.

[63] B. Poudel, Membrane bioreactor (MBR) plant for treating dairy wastewater: an indepth look at the Arla milk powder factory, The MBR Site, accessed March 2016.

[64] S.C. Low, K.T. Cheong, H.L. Lim, A vibration membrane bioreactor, Desalin. Water Treat., 5 (2009) 42-47.

[65] Spintek filtration, Membrane filtration, www.spintek.com, 2016.

[66] M.R. Poirier, D.T. Herman, D.B. Stefanko, S.D. Fink, Testing a rotary microfilter for Hanford applications, WM2009 Conference, 2009.

[67] T. Leonhardmair, (2015), priv. comm.

[68] Novoflow Gmbh, Filters, www.novoflow.com

[69] G. Genkin, T.D. Waite, A.G. Fane, S. Chang, The effect of vibration and coagulant addition on the filtration performance of submerged hollow fibre membranes, J. Membr. Sci., 281 (2006) 726-734.

[70] A. Kola, Y. Ye, A. Ho, P. Le-Clech, V. Chen, Application of low frequency transverse vibration on fouling limitation in submerged hollow fibre membranes, J. Membr. Sci., 409-410 (2012) 54-65.

[71] T. Li, A.W.K. Law, M. Cetin, A.G. Fane, Fouling control of submerged hollow fibre membranes by vibrations, J. Membr. Sci., 427 (2013) 230-239.

[72] J. Ho, S. Smith, G.D. Kim, H.K. Roh, Performance evaluation of a novel reciprocation membrane bioreactor (rMBR) for enhanced nutrient removal in wastewater treatment: A comparative study, Water Sci. Technol. 72 (2016), 917-927

[73] J. Ho, S. Smith, J. Patamasank, P. Tontcheva, G.D. Kim, H.K. Roh, Pilot demonstration of energy-efficient membrane bioreactor (MBR) using reciprocating submerged membrane. Water Env.t Res., 87 (2015), 266-273

[74] S.C. Low, H.H. Juan, L.K. Siong, A combined VSEP and a membrane bioreactor system, Desal., 183, (2005) 353-362

[75] I. Ruigómez, I., L. Vera, E. González, G. González, J. Rodríguez-Sevilla, A novel rotating HF membrane to control fouling on anaerobic membrane bioreactors treating wastewater. J. Membr. Sci. 501 (2016) 45-52.

[76] J. Ho, S. Smith, H.K. Roh, Alternative energy efficient membrane bioreactor using reciprocating submerged membrane, Water Sci. and Technol. 70 (2014) 1998-2003.

[77] R. Montañez, (2013), priv. comm. 
[78] M.R. Bilad, G. Mezohegyi, P. Declerck, I.F.J. Vankelecom, Novel magnetically induced membrane vibration (MMV) for fouling control in membrane vibration, Wat. Res. 46 (2012) 63-72.

[79] M.R. Bilad, V. Discard, D. Vandamme, I. Foubert, K. Muylaert, I.F.J. Vankelecom, Harvesting microalgal biomass using a magnetically induced membrane vibration (MMV) system: Filtration performance and energy consumption, Biores. Technol., 138 (2013) 329-338

[80] S.P. Beier, G. Jonsson, A vibrating membrane bioreactor (VMBR): Macromolecular transmission-influence of extracellular polymeric substances, Chem. Eng. Sci., 64 (2009) 1436-1444.

[81] D.Y. Zuo, H.J. Li, H.T. Liu, G.P. Wu, A study on submerged rotating MBR for wastewater treatment and membrane cleaning, Korean J. Chem. Eng. 27 (2010) 881885. 